'Cheese makers are always women':

gendered representations of farm life in the agricultural press

*Carol Morris and **Nick Evans

*Countryside and Community Research Unit, Cheltenham and Gloucester College of H.E., Francis Close Hall, Swindon Road, Cheltenham, Gloucestershire, GL50 4AZ. Email: cmorris@chelt.ac.uk

**Department of Geography, University College Worcester. Henwick Grove, Worcester, WR2 6AJ. Email: n.evans@worc.ac.uk 


\title{
'Cheese makers are always women': gendered representations of farm life in the agricultural press
}

\begin{abstract}
Drawing upon the 'Farmlife' pages of Farmers' Weekly, the most significant farming publication in the UK, this paper assesses the ways in which gender identities in farming are represented by its text and images. Lead articles from 1976 and 1996 issues of Farmlife are taken as the research focus to determine how representations have altered in line with restructuring of the agricultural industry. Reference is made to Connell's (1987) notions of hegemonic masculinity and emphasised femininity to inform the analysis about the ways in which these gender identities are (re)produced through the British farming media. A simple typology is derived from the articles which assists in revealing a remarkable degree of consistency in the portrayal of gender identities over time. The findings augment evidence from international research suggesting that dominant gender identities within agriculture are being perpetuated through the farming media. The implications of this are highlighted and suggestions made for research with the consumers of these media products.
\end{abstract}

\section{Representations of rural life}

According to Fish and Phillips (1997, p.1), a key point of articulation between rural studies and the cultural turn has been the increased attention given to "representations of the countryside and how they are created, circulated and consumed, and also how they may influence material actions". They further observe that there has been "a concern with examining how these representations are embedded in relations of power" (see also Cloke, 1997; Little, 1999). Researchers interested in gender issues in rural areas have undertaken a small proportion of this work on representation, with media products providing one source for analysis. For example, based on their examination of 'Country Life' magazine, Agg and Phillip's (1998, p.262) make the observation that "many images of villages in the countryside reflect a heterosexual masculinism in that they emphasise and naturalise the conjugal family, bodily differences between men and women, the power of men in the official sphere and the importance of women in the unofficial sphere". Meanwhile, Walter and Wilson's (1996, p.227) research on 'farming success stories' in the North American agricultural press has revealed that women tend to be neglected in these accounts, creating and perpetuating a 'domestic ideology' in agriculture which constructs “men as farmers and women as nurturer, 
mother, wife, helpmate and homemaker". This view is also supported by Liepins (1996) in the Australian context. Representational work of this nature has begun to provide interesting insights into farming femininities and masculinities and the role of the media in the (re)production of these gender identities (see also Brandth, 1995; Brandth and Haugen, 1997). This provides a theoretical basis from which to examine the many agricultural representations that remain to be explored in a British context.

A popular approach in the international literature has been to analyse the relational aspects of the representation of women and men within the main sections of agricultural papers and magazines (Walter and Wilson, 1996; Liepins, 1996). A common conclusion has been that technical issues associated with production or policy developments in the farming sector are masculinized. Consequently, a major problem is that investigations are based on very limited representations of women in these sections of the agricultural press. An important omission therefore in research of this nature is a study with a point of entry where the most abundant and overt representations of farm women are located through an analysis of the content of 'women' and 'family' pages in the farming press. Specific research attention is justified because it is within these pages that life in the farm household, and relations between all its members, are most explicitly revealed.

The women and family pages of the agricultural media provide the focus for this paper, specifically, the 'Farmlife' section of the popular British publication, 'Farmers Weekly'. The main objective is to analyse the representation of gender identities in agriculture within 'Farmlife'. The paper will discuss the extent to which these representations have been sensitive to the restructuring of the British agricultural industry over recent decades and the implications for gender relations that this has entailed. A further objective is to stimulate interest and debate in feminist research on British agriculture which has recently been characterised by a loss of impetus. This contrasts with the international context in which farm women have continued to provide an important focus for rural researchers, albeit with a somewhat different emphasis to previous work on gender roles and relations in agriculture (Gasson, 1980 and 1982; Whatmore, 1991a). Particular effort has been directed towards the organisation of farm women 'off-farm', in the form of agricultural activism and politics (Haney and Miller, 1991; Mackenzie, 1994; Leipins 1995 and 1996; Teather, 1996; Brandth and Haugen, 1997; Leipins 1998). Furthermore, a rich variety of research has been produced 
over the past decade which has examined the lived experiences of non-farming women in rural areas of the UK (see Whatmore et al., 1994; Little and Austin, 1996; Hughes, 1997; Little 1997a \& b; Fisher 1997).

The paper begins with a conceptualisation of the agricultural media and outlines the relevance of Connell's (1987) work on the representation of gender identity in the mass media.

Methodological issues surrounding research based on the media are considered before the paper moves on to review the changing nature of Farmlife. A simple typology of articles is presented which is used to describe the content of the representations of femininities and masculinities within Farmlife and to interpret critically how particular values and meanings are used in the construction of these representations. The paper concludes with a discussion of these findings and their implications for the (re)production of gender identities in British agriculture.

\section{Gender identities and the agricultural media}

Interest in the representation of farming life within the agricultural media reflects a wider recent concern with the media as a source for geographical research (Burgess and Gold, 1985; Burgess, 1990 and 1993; Parisi and Holcomb, 1994; Jackson et al., 1999). In an agricultural context, the media has been conceptualised as both sites and processes in the construction of meanings (Liepins, 1996; Brandth and Haugen, 1997). First, farm media products (articles, photographs and advertisements) are seen as important sites where meanings about gender identities in agriculture are created. Media products are understood as impartial and valueladen, composed within distinctive contexts by journalists following particular conventions, ideologies and editorial policies. In short, the media "operate to promote certain views of the world that favour existing social relationships and dominant ideology at the expense of other views" (Hall, cited in Lowe and Morrison, 1984, p.77). Secondly, media products are more than just sites of meaning construction and can also be understood as embodying processes relating to the production, circulation and consumption of meanings about gender identity. This notion of the media as a continuous process, or circuit (Burgess, 1990), encompasses the idea that the agricultural press "participates in the social shaping of rural women's identity" (Brandth and Haugen, 1997, p.330). Agricultural media representations can have material effects by impacting upon gender identities on farms. In turn, these social processes shape future media representations (Brandth, 1995; Fish and Phillips, 1997; Agg and Phillips, 1998). 
It would be necessary to study the many different 'readings' or 'decodings' of the agricultural press by farm women and men to draw conclusions about the media as a process of meaning construction, but this is beyond the scope of the paper. Instead, in this research, effort is focused upon the media as sites of meaning construction. Texts and images are scrutinised critically to enable identification of the prevailing norms and values about gender identity that have been drawn upon in their construction.

In approaching the agricultural media as sites of meaning construction, the research builds upon Agg and Phillip's (1998) application of Connell's (1987) ideas, on gender identity and the mass media, to the analysis of the non-agricultural countryside media. Two important assumptions about gender are tied up in this work. First, gender is accepted as an analytical category central to the understanding of social change. Second, the notion of essential or natural gender divisions are rejected and instead, gender divisions and identities (meanings about what it is to be a man or a woman) are understood as socially, geographically and temporally constituted and subject to constant contestation and revision. Although Connell (1987) recognizes the possibility of many different masculinities and feminities existing as multiple gender identities, he argues that two constructions of gender identities are most common. These are 'hegemonic masculinity', in which men are defined by their physical power and economic strength, and 'emphasised femininity', where women are constructed as nurturing and compliant. Such identities are understood as having common roots in heterosexuality and as relational, involving each other in their own construction. The identity of hegemonic masculinity is the dominant pole of the dualism, with emphasised femininity and other male and female identities located in a subordinate position. Connell (1987) suggests that the two gender identities of hegemonic masculinity and emphasised femininity prevail in the contemporary mass media, with individual identities structured in relation to these 'public' identities. Research has yet to ascertain whether similarly dominant constructions of gender identity are evident in the British farming media, let alone question the existence of competing constructions within and between different time frames.

Although a helpful means of structuring analysis of the agricultural media, it is acknowledged that aspects of Connell's (1987) work are problematic, particularly in the light of recent feminist debates about the need to move beyond knowledge construction through dualisms (Butler, 1990; Rose, 1993; Massey, 1994; Massey, 1996; Women and Geography Study 
Group, 1997). The rejection of dualistic thinking in itself is accepted as desirable, but the intention here is to examine and critique the extent to which powerful institutions, in this case the agricultural media, continue to draw upon and replicate ingrained dualistic constructions of masculinity and femininity.

\section{Methodology}

Accepting that media products are not neutral or impartial implies that their use must involve critical analysis of the purpose and content of that product. This is briefly considered before the research methods employed are discussed in detail. As suggested earlier, Farmer's Weekly represents the most popular media source of information about agriculture to the farming community in Britain. It is a vociferously pro-farming magazine that is keen to defend farmers' interests, often by running campaigns addressing specific issues such as those to 'cut red tape' and to publicise that 'British beef is best'. Farmers Weekly attempts to portray 'on the ground' farmer opinion over a wide range of issues. The aim is to appeal to the farming community thereby maintaining sales within its market niche, explaining the adoption of this particular agenda. The magazine is circulated to both individual and institutional subscribers, and it claims a readership of approximately 290,000. Hypothetically, this represents $85 \%$ of full-time farmers and farm workers in the UK. Of course, the magazine will be available to many more members of farm businesses and households, so that a significant proportion of the UK farming population accesses this journal.

Farmer's Weekly is a substantial publication, on average 125 pages long. The typical format comprises an editorial, latest news, a business and markets section, specialist livestock, arable and machinery sections, features and readers' letters, together with classified advertisements. The Farmlife pages occupy the final 5-10 pages of the magazine as a distinct sub-section with its own editor, having first appeared in the mid-1800s as the 'Home Section'. For many years it was aimed exclusively at female readers. As the editor describes, the pages were originally designed to "provide something for farmer's wives in response to reader request or market study" (Rogers, 1997, pers. comm.). It became the 'Magazine Section' in the 1960s, a change that heralded a move away from the 'ladies only' [sic] outlook. According to Rogers, the pages are "the non-technical end of the paper, including anything in which the farming family might be interested". Even so, the aim is that they are not seen as 'women-only' pages, but rather that to have "broad appeal ... our stories are not just about women. The 'stars' of our 
stories are just as likely to be men as women". It also tries to appeal to young and old alike. Describing the regular features, many of which claim to provide a farm woman's perspective on farming life, Rogers (1997, pers. comm.) suggests that "these are not deliberately sexist, but offer a balance to the farming diaries in the stock and sales section and a window into farm family life - it is an occupation which rules the lives of all the family and not just the person carrying out the job".

To assess any change in the representation of farm women in the Farmlife pages over time, all 101 lead articles published in 1976 and 1996 are scrutinised for analysis. The justification for this choice is as follows. In 1976, agricultural policy was reaching the end of a long period of stability that placed firm emphasis on maximizing food production. The 1947 UK Agriculture Act promoted a progressive industrialisation of the industry through the commonly cited processes of intensification, concentration and specialization (Bowler, 1985). Intensification and specialisation have made farming more technical, requiring the development of specific labour skills or the attainment of proven levels of competence (as with the need for certificates to apply agro-chemicals) in outdoor duties with which men are most frequently involved. For many farm women, this has led to a masculinisation of agriculture as machinery has replaced the contribution they had previously made to land-based activities (Almas and Haugen, 1991). Geographically, the most potent effects of these changes have been felt in the lowland arable sector of agriculture, with farm women in the upland livestock sector remaining most closely aligned with the supply of outdoor labour (Evans, 1990). Concentration, or farm amalgamation, summarizes a trend in which farms have become fewer in number but larger in size. However, contrary to some theoretical predictions, especially those based on Marx's evolutionist thesis, it is estimated that $90 \%$ of farm businesses remain family run (Marsden et al., 1996; Gasson et al., 1988). Those that are of medium size (commonly regarded as between 20 and 300 hectares in size) have experienced greatest pressure for survival in business (Marsden et al., 1987). A common response has been to shed hired (non-family) labour whilst simultaneously increasing the level of self-exploitation of contributing family members. This has served to reaffirm women's domesticity and reproductive roles in the farm family. Against this backdrop of general agricultural change, it might reasonably be expected that the 1976 Farmlife reports will be broadly characterised by: celebrations of productive agriculture; reports of family farm businesses successful in (re)production; features on the impact of new technologies in agriculture; portrayals of farm women in domestic and reproductive situations. 
The selection of 1996 represents the first full year of magazines available when the research commenced and provides a picture of contemporary representations of farm women.

By this time, the agricultural industry in Britain had experienced large-scale and widespread restructuring. The uni-dimensional goal of increasing food production became both politically unacceptable and economically inadequate to sustain many small and medium-sized family farm businesses. From the mid-1980s, it was the contribution of farm women to the business that became acutely redefined. Of special relevance is the dramatic increase in opportunities for farm women to generate income from on-farm diversification into non-agricultural enterprises (Evans and Ilbery, 1996). Non-farming activities have grown in relative importance to land-based production as factors in income generation and business survival. These new roles are often additional to 'traditional' domestic roles of farm women based on a patriarchal division of labour. However, land-based (outdoor) diversification ventures such as camping and caravanning accommodation enterprises still tend to remain under the control of men alongside 'mainstream' food production activities (Evans and Ilbery, 1992). It can be anticipated that, compared with Farmlife articles in 1976, those in 1996 will, at the very least, place a greater emphasis on: portrayals of women making an income contribution to farm businesses through activities not based on production from the land; examples of quality in food production and advice on its marketing; the natural environment and healthy living; and 'women farmers' as entrepreneurs within new agricultural business structures.

Attention is confined to lead articles in Farmlife as they are typically substantive relative to the other pieces ${ }^{1}$. A proforma was devised to gather information from them. It records: the topic and style of the article; personal, professional and biographical details of the women portrayed and their relationship to farming activity; the activities of the women featured; the personal and professional status of men and whether or not men are absent from articles. Also noted is the extent to which women feature, be they: central to the article, where the focus is a woman's hobby or business activity; of equal importance, where women are represented as business partners; of marginal importance, where they are mentioned only as wife or daughter of the man who is the focus of the article; or not mentioned at all. The representation of

\footnotetext{
${ }^{1} 1$. For ease of referencing, only the date of each Farmers' Weekly article is provided after the quotations that follow. The Farmlife pages are separately numbered to those that comprise the main body of the magazine. All lead articles therefore are found on page 1.
} 
women in accompanying photographs, apposite quotes, overall impressions and comments on the piece examined complete the scrutiny. The process of data collection enables both a quantitative assessment of the articles through content analysis and a more qualitative interpretation of implicit values and meanings. Using this methodology, the analysis is divided into two sections. First, an overall impression of Farmlife in each of the two decades is presented, outlining its core concerns and those issues notable by their absence. Secondly, a typology of articles is derived from examinations of the content to reflect common themes emerging from them. This thematic typology is used to discuss the changing content of Farmlife and to facilitate a more discursive reading of the articles. It is not intended to be a definitive or rigid classification of Farmlife articles.

\section{The changing nature of Farmlife}

Farmlife covers a surprisingly limited range of issues and activities. Features about 'modern' agricultural life (for example, large-scale contract cherry farming) are presented along with evocations of tradition and nostalgia, as demonstrated by reporting on farm museums, 'traditional' production practices and local farming personalities. Although international and national contexts are present, the emphasis is firmly upon 'local' spaces and places, particularly individual farm holdings and the domestic sphere. Both public (community places and events) and private (home / domestic) spaces are included. In agreement with Brandth and Haugen's (1997) observations on a Danish rural women's magazine, women in Farmlife are rarely featured as those who break with tradition and norms, or are in some ways social innovators. Nevertheless, exceptions are present, especially in recent copy. Women and men are represented as individuals, but more frequently presented together, usually in relation to one another (as a wife or husband) and typically in the context of an 'idyllic' construction of farm family life. Lead articles seldom give detailed consideration to relations between women and men and certainly do not portray them as problematic. It is left to the letters pages of Farmlife to discuss occasionally the frequently subservient position of farm women and any social or emotional difficulties associated with being a farmer's wife. This reflects the general tone of Farmlife which seems to strive to be apolitical and non-controversial, both in general terms and in relation to issues of particular relevance to women. Absent are reports on issues such as drug use, domestic violence, sexuality, safety and fear of crime which are known to impact upon rural ways of life (Cloke, 1997). Indeed, Farmlife's self-determined brief to cover 'family life' legitimises ignorance of these issues by virtue of their unsuitability in this 
context. Ironically, though, there are few features of direct interest to children, such as reports on popular culture or alternative career pathways to agriculture.

Farmlife in 1976 differs fundamentally from the 1996 volume in two ways. First, in spite of Farmlife's lifestyle remit, a proportion of articles in 1976 focus upon the 'business' of agriculture. Moreover, as anticipated, celebrations of the productiveness of agriculture are evident from reports on agricultural shows in particular, but also in the training of agricultural workers and articles on stockmanship. Two articles also cover the drought of that year and its detrimental impact on farm output. This is not surprising given the unidimensional postwar goal of increasing food output that was still being followed unwaveringly in 1976 (see for example, the government White Paper of 1975 entitled 'Food From Our Own Resources'). By 1996, there are more articles dealing with alternative farm enterprises (pluriactivity) as exemplars of farmers' and farm households' ingenuity in overcoming falling incomes from food producing activities. Little direct consideration is given to mainstream agriculture compared with the earlier volume.

Secondly, many more articles in 1976 feature the activities of hired farm workers whereas the 1996 emphasis is on farmers and immediate family heading the business. Again, this reflects restructuring within the agricultural industry, notably the long-term decline of the farm workforce due to technologically based substitution (Gasson and Errington, 1993). Additionally, as the farming community has shrunk and new types of resident have moved into rural areas, articles on farm workers have been replaced by features on people who possess tenuous farming connections. For example, there is a feature on a Lincolnshire chip shop with the last coal-fired cooking range in the country run by an 81 year old woman. The catering angle is presumably of broad appeal to women, but it is an obscure link with farming that is stressed: "Many local farmers and workers are regular customers. We sell a lot of fish and chips at harvest to farmers. Their wives fetch them so their husbands don't have to take too long off the combine" (26.7-1.8.96).

Similarly, an article about a woman artist stresses that she paints farmers and farming scenes, even though the accompanying photograph of her work reveals that her work contains many non-farming subjects. Moreover, the article is keen to establish that "although not a farmer's daughter, she was brought up in a farming community" (19-25.7.96). In each case, the social 
imaginations of what it means to be 'rural' are exploited (Phillips, 1998). Indeed, a feature of 1996 Farmlife are demonstrations of the achievements in farming by members of its' community. Reference is made to agricultural activities which, in reality, have little bearing on the activity which purports to be the central focus of the reporting. For example, the success of a young woman in an Eisteddfod singing contest is featured, yet the ability of her father in breeding rare breed Balwen sheep is repeatedly emphasised (18-24.10.96).

\section{A typology of Farmlife articles}

Seven recurrent themes can be identified in Farmlife. Each is adopted as a typological category and is used as a basis for further discussion (Figure 1). Assigning an article to one of these categories is not always straightforward. Cases can contain more than one theme, such as business activities and domestic issues. With the 'Craft activities' and 'Operating a business' categories, a distinction is evident and useful in many cases, but in others it is difficult to distinguish a difference. In these situations, judgements have to be made about the dominant theme of an article. All categories, except those dealing with 'Politics' and 'Conservation', can be derived from both the 1976 and 1996 data sets. By 1996, no articles could be assigned to the political category, with the new conservation category replacing it. Tables I and II summarise the collective findings from the selected Farmlife features and respectively: present a breakdown of the number of articles within each of the categories in each year; describe the relationship between each category and articles where the focus of the reporting is activities in which women are the protagonists.

\section{FIGURE 1 HERE}

\section{Operating a business}

Articles featuring business activities have become more significant over time. In 1976, articles give equal coverage to the themes of community, domesticity and recreation (Table I). The dominance of business oriented articles in 1996 undoubtedly reflects the relatively poor state of the agricultural economy in the 1990s that has forced the 'business' of farming to become more central to farm households than farming 'as a way of life'. None of the articles, in either of the years, portray women as 'farmers', participating full-time in conventional agriculture. In contrast, where men feature, they do so solely in an agricultural capacity as, for example, 
coping with the problems of upland sheep farming or niche marketing unusual varieties of potato.

\section{TABLE I HERE}

Further, relatively few articles in the 1976 sample feature women centrally in a business role (Table II). For example, they report on a female manager of a family run rural shop on the brink of closure (26.11.76) and a farmer's wife who has set up her own beauty and cosmetics business using natural ingredients (herbs and wildflowers) found on the farm. In the latter case, the woman depicted is educated and has taken the initiative to establish this successful business venture. However, the article places less emphasis on the woman's achievement in business and more emphasis on the nature of the product itself, one that is designed to improve women's physical appearance. There is also a sense that the activity reported is not particularly serious and marginal to the farm business, as illustrated by the opening line that states: "Janet Carter could not find a skin food to suit her dry complexion ... all that Janet has to worry about is for how much longer her sturdy food mixer can go on churning out all those little pots of natural skin care" (13.8.76).

\section{TABLE II HERE}

Even where women are featured in business alongside their husbands, closer examination reveals a gender inequality both in the content of the reporting and the reality of the situation being represented. Despite being of equal importance to the functioning of a business, biographical details of each partner tend to be dominated by reporting of the husband's activities. For example, one story depicts a farming couple who have established a post-office on their farm (15.10.76). The woman in this couple initiated the idea and runs the shop most of the time. However, it is the farmer who describes himself as the 'postmaster' and goes to the cash and carry. Meanwhile, his wife assumes responsibility for all child care and business accounts, as well as contributing to farm work. Her labour burden has increased whilst there is little evidence of any increase in her decision-making power within the business, nor recognition of these issues in the reporting (see also Evans and Ilbery, 1996 on farm diversification). Moreover, her domestic responsibilities remain unchallenged. 
The number of business-oriented articles where women are central to the reporting increases dramatically from 23\% in 1976 to 53\% in 1996 (Table II). The majority of business activities depicted are based on the farm, with some unrelated to farming such as a cake baking business and manufacturing waterproof children's clothing. Others are directly related either to agricultural production, including value-adding activities such as cheese production, or to making products likely to be consumed by members of the farming community (for example, show rosette making). Some of these articles depict women achievers, those who are educated, successful and active participants in the wider farming community. This is illustrated by the example of one farm woman, Mary Quicke, who has established her own traditional cheddar cheese making enterprise on the family farm. With a Ph.D. in English literature and a previous career in journalism, she returned to the family farm when none of her siblings expressed an interest in maintaining the agricultural business. In addition to running the cheese business (aided by her husband who markets the product), she is actively involved in a number of agricultural organisations off-farm, yet retains her family responsibilities (1.3.96).

Despite Farmlife's emphasis on business reporting, the majority of these female-run ventures can be seen to represent a commodification of women's traditional domestic role within the farm household. A farm woman's success in business thus becomes legitimised because it is 'women's work'. In the words of Mary Quicke, from the example above, “at Quickes, all the cheese makers are men and they seem to have little problem with the business being run by a woman. In all the old books, cheese makers are always women". The extent to which these activities are contributing to farm income is rarely detailed and the relative improvement in the 'professional' status of women through these activities is typically accompanied by neither a change in their decision-making status in the farm business nor a reduction in their domestic duties. Thus, the reader is left in no doubt that the business women depicted are still the wives of farmers. Indeed, there are constant reminders that these business women remain wives and mothers. Again, to quote from Mary Quicke, "home life is very important to me. I enjoy the children and it is such a privilege to be a mum. You can get swept away by work things and self importance, there are already too may superwomen out there" (1.3.96).

As in their 1976 portrayal, men are featured as farmers in some 1996 articles. Nevertheless, by 1996, other articles show males drawn into value adding (on agricultural products) and a 
range of non-agricultural business activities such as the production of fruit beverages, processing cob nuts and organising World War One battlefield tours. This reflects a general process of agricultural restructuring towards multiple income sources. In the depiction of these activities, where women are frequently represented in a supportive or marginal position, there is a noticeable patriarchal gender division of farm labour as a feature entitled 'A fine line in festive pine' reveals. This reports a farming couple growing Christmas trees (on-farm 'agricultural' diversification, see Evans and Ilbery 1993) and employing a unique marketing idea involving delivery and collection of trees. The husband takes care of the outdoor activities (the outdoors remains the male domain) whilst his wife paints terracotta pots indoors in which the trees are planted (6-12.12.96).

\section{Rural community life}

There has been a reduction in the number of community-oriented articles between the two years. One possible explanation is that the period has witnessed a decline in the farming population and associated disruption in farm-centred rural communities (Newby, 1979; Murdoch and Marsden, 1994). Also, the agricultural crisis of the mid-1980s tended to shift the focus of attention of farm families towards survival of their individual farm business and away from contributions to a wider community (Marsden et al., 1989). In those articles that remain community-oriented, women are increasingly central, rising from 8\% in 1976 to $16 \%$ in 1996 (Table II). This may be indicative of the greater participation of farm women in rural labour markets as a result of pressure to diversify agricultural income sources and the wider constituency of contacts, activities and outlook that this may engender.

Comparing the way gender is treated in articles from each year, four observations are possible. First, there is continuity between the types of community activities featured in both years examined. For example, a 1996 article on farm women organising after-school 'kids clubs' (13-19.12.96) replicates a 1976 report on women setting up rural play groups to help socialise isolated farming children (30.4.76). The reporting of women in these articles is revealing of gender roles and relations on farms. For example, a rural development officer comments: "It is not simply that farmers wives don't understand that small children should meet as many people as possible ... They are just too busy. I don't think that there is another group of women who are so bound up with their husbands work as farmers wives are ... They are far more tied to home. Even when they don't work on the farm, their husbands expect them to be there. 
Watch the reaction when a farmer is told that his lunch won't be on the table at 1.00 o'clock because the child has to be taken to playgroup ... Mother can't take the child to playgroup by van if it is needed on the farm" (30.4.76). Secondly, new dimensions of female community participation appear in 1996. This is illustrated by efforts to develop community activities on an international scale through an African aid scheme run by a farmer's wife (20-26.9.96). Thirdly, 'women achievers' now feature within this category of article as demonstrated by the portrayal of a highly qualified female vicar and her work within rural Northumberland (23.2.96). Fourthly, farm men and women are represented undertaking different types of community work in 1996 compared with 1976, yet a subtext suggestive of 'appropriate' gender roles persists. The tendency to portray women undertaking those types of 'hands-on' community work associated with traditional gender roles of nurturer and carer contrasts markedly with the typical representation of men involved in 'hands-off' community activities such as fundraising and organising farm open days.

\section{The domestic sphere}

Given the stated brief of Farmlife to emphasise farm family life, it is perhaps surprising that more 1976 articles do not feature domestic topics (an equal number of business and domestic articles appear in this year). The impact of drought on one farm wife's ability to keep the house clean whilst the male farmer worries about how to provide enough drinking water for his cattle (27.8.76), a report of the winner of a 'supermum' competition (10.12.76), and a cookery competition featuring the prize of a heated hostess trolley (26.3.76) are indicative of women's centrality in farming domesticity. Where domestic-oriented articles portray women in an equal or supportive role, analysis of the text reveals the same gender division of labour as presented in articles where women are central. For example, a report on farm safety reports the concerns of a farmer's wife to protect children from the dangers of farm machinery (23.7.76). Here, the men are depicted operating the dangerous machinery whilst the women, in their child-caring role, prevent children from accidents associated with this machinery. Another domestic oriented article featuring an unusually large farmer (6ft 8in, size 15 shoes) actually concentrates on the problems his size presents to his wife when buying him his clothes: "Persuading the menfolk to buy, and wear, new clothes is a headache for many a farmer's wife. Hedy Stapel-Valk has the additional trial of finding shops which sell clothes large enough to cover her husband's great frame" (14.5.76). 
Another article describes a farm worker who had married a Bulgarian woman and together they moved back to England, or as the article put it, "He brought a little bit of Bulgaria back home with him" (27.2.76). The view that women belong in a domestic role on the farm is evident to the extent that a working woman is taken to be indicative of a nation's underdevelopment as the full quote testifies: "The country [Bulgaria] is vastly underpopulated and the young married women are constantly being encouraged to have more children. For instance, the family allowance has been increased so that wives will not need to go out to work. Even so, most family incomes depend upon the wife working." The fact that women may want to work to escape domesticity remains unconsidered at this point in time. Domestic-oriented articles no longer feature in 1996, having been replaced by those portraying domesticity with a commercial purpose.

\section{Recreational pursuits}

The number of articles featuring hobbies or recreational activities remains similar between the two years. However, significant differences can be observed in the depiction of men's and women's recreation within and between each of the years examined. In 1976, women are only featured in indoor recreational pursuits which emphasise their physical appearance and personality. Thus, one article reports on a fashion show at the Royal Agricultural Show where farmer's daughters and wives participated in a competition to model their own clothes (16.7.76). The views of the organiser are reported in an interview: "It seems old fashioned but we were looking for the ones who walked well - head up, shoulders back. We were also looking for a pleasant smile...These three all had nice skin and shiny, clean hair and they had co-ordinated their outfits well. I was most impressed". The same organiser was not so impressed with those competitors who had chosen to wear "heavy platform shoes"! Another article describes the success of a slimming club set up by a group of farmer's wives in Derbyshire (20.8.76). The accompanying photos, featuring a number of the group members 'weighing in' have captions which include the following comments: "The sylph in the pencilslim skirt said, "I was once a tight size 16. Now I'm a tight size 12"; "The worst temptations? Sweet foods, bacon and egg breakfasts which they cook for their husbands and fruit squashes". Both of these articles clearly demonstrate patriarchal assumptions about the importance of female beauty and appearance. By contrast, men are portrayed overwhelmingly in outdoor activity and achievement based pursuits such as rugby playing, tennis umpiring, and racehorse training . 
In those 1976 articles where men take centre stage, reaffirmations of the meanings and expectations of being a 'wife' come through representations of recreation activities, emphasising a role supportive to the husband. For example, one farm worker collected coins as a sideline and had started dealing in them to supplement household income (20.2.76). He controlled all financial aspects of the activity whilst "his wife Bonnie helps in the business, dealing with the post and preparing the catalogue". The purpose of the coin dealership is clearly stated as helping to meet the husband's aspirations to cease being an agricultural worker and purchase a farm. Alternatively, husband's hobbies are constructed as benefiting the wife. In one extreme case, the products of a silversmithing hobby are used to reward the wife for doing farm work in preference to monetary remuneration: "Wife Dinah, of course, benefits from Warwick's [the husband] hobby. She has a beautiful gold set with an emerald and diamond, as well as a silver bracelet and brooches. But then she helps him out on the farm" (6.2.76).

By 1996, articles reporting women's recreational activities shift towards activity and achievement based hobbies including photography, singing, breeding gun-dogs and running caravan sites. This range of activities suggests that the agricultural media is no longer intent on assigning farm women to passive, indoor hobbies which focus on their physical attributes. Nevertheless, comments made within these articles provide evidence that these activities take place within the context of a continuing traditional gender division of labour on the farm. For example, one farmer's wife whose hobby is taking and developing photos of farm life has no intention of becoming a full-time photographer: "There isn't time when you're a farmer's wife...but after 20 years of being at home taking a course on photography is tremendous" (28.6.96). Also, it is apparent that men continue to participate in more prestigious and conspicuous hobbies in their leisure time. Thus, men are variously depicted renovating barns, racing motorbikes, corn milling, winning model tractor competitions and tending to the conservation of historic monuments.

\section{Craft activities}

Continuity is evident in the types of activities depicted in craft-oriented articles. For example, in both years, women are shown cheese-making, dyeing and weaving rugs and doing embroidery. However, two elements of change can be observed. First, women continue an 
involvement with crafts in 1996, but men no longer appear. Secondly, fewer articles report craft activities (from 10\% in 1976 to $4 \%$ in 1996). Rather than being a part of traditional, small-scale production, these farm-based crafts have been commodified into business activities as part of the wider shift towards the consumption of the countryside (Short, 1991; Marsden et al., 1993). One example which helps to highlight this transformation comes from 1976 in which one farm woman was attempting to produce (but not on a commercial scale) traditional Double Gloucester cheese from rare breed Gloucester cattle. This is an activity of mainstream importance to the future of farming in late 1990s as it simultaneously captures issues of a quality food product, conservation of rare breeds of livestock and an income earning 'value adding' diversification activity (Yarwood and Evans, 2000). Even in 1976, the importance of the activity is recognised, but it is devalued by the prevailing patriarchal power relations on the farm: “...she hopes that Gloucester cheese made from Gloucester Cattle will not only be a good marketing point but will also put this ancient breed back on the map... They are traditionalists. Monica even wears a skirt to do the farm work. Charles does not approve of women in trousers" (23.1.76).

\section{Politics and Conservation}

Women do not feature centrally in either of these categories (Table II). Typically, they are not represented at all whereas men appear as a local mayor, conservation officer and agricultural adviser. Elsewhere, women tend to be mentioned in passing, such as 'the wife of a conservation-minded farmer', or are referred to in a light-hearted manner during the treatment of serious issues, as demonstrated by a 1976 article reporting the involvement of a woman in farming politics at a National Farmers Union conference: "Talking of ladies, not every delegate leaves his wife at home. Quite a few grace the gallery seats, and one or two sit among the delegations. Mrs Cowper of Evesham Growers branch is at the rostrum to make a plea for an NFU 'think tank' to develop new strategy. Overcoming the obstacles of a close-fitting skirt and a high step to the lectern, she speaks forcefully but her resolution is defeated" (30.1.76).

Although trivialised in 1976, it is rather surprising to find that by 1996 no Farmlife articles make a direct link between women and agricultural politics. As noted in the introduction, international research has revealed an increasing politicisation and activism amongst farm women. Farmlife displays the opposite trend, apparently favouring in its reporting local community activism over the wider political involvement of farm women. A new emphasis on 
conservation in Farmlife reflects the greater importance attributed to environmental stewardship that is filtering down from mainstream agricultural policy. There is anecdotal evidence to suggest that women play a role in persuading their spouses to adopt environmentally friendly farming practices on the farm. Further research on this assertion is needed to demonstrate that this is not simply a gender-loaded assumption derived from preconceptions about women's role in nurture and 'mother' nature. The male-biased conservation reporting in Farmlife suggests that although such articles are selected on the pretext of broad appeal to women, gender divisions are maintained because conservation necessitates the traditional male-based preserve of land management. Even within the newest concepts introduced to the farming community, patriarchal ideologies appear to retain a dominant influence in media representations of farming activities.

\section{Gender identities and Farmlife: new perspectives on old orders?}

This typological discussion provides unequivocal evidence for the use by the agricultural media of a distinctive, dualistic construction of gender identity as Connell (1987) suggests is apparent in the context of the mass media. In 1976 representations, hegemonic masculinity and emphasised femininity are explicit both in the language used and in the depiction of the activities in which women and men are involved. It is particularly striking how femininity in the agricultural context is narrowly constituted through domestic roles and spaces and the degree to which such domesticity goes unchallenged. This is demonstrated quantitatively in Table II as more women are depicted centrally in domestic articles in 1976 than in any other category. Women do not appear in commodity production roles and where mention is made of their contribution to farm work little detail is provided. This contrasts with the representation of men who appear solely in these roles, supporting the idea of hegemonic masculinity. The dominance of emphasised femininity lends support to Leipin's (1996, p.5) assertion that women in the Australian agricultural press are: "constructed as wives, mothers, and homemakers devoted to home, community service and ancillary support work on the farm. On these occasions they are provided with their own pages in marginal positions inside the papers where discourses of family, heterosexual partnerships, motherhood and domesticity contextualise the texts that are published".

By 1996, changes in the representation of femininity in Farmlife can be discerned.

Superficially at least, it would appear that there has been a movement away from emphasised 
femininity. Notably, a more 'gender sensitive' language is employed, articles with a domestic focus no longer feature, farm women are presented in a wider diversity of roles than previously and there is a virtual absence of references to women's physical appearance. Additionally, 'women achievers' now have a place within the stories either as highly qualified women running their own businesses (on or off-farm) or as participating in a range of outdoor and achievement based leisure pursuits. Female assertiveness is also present (although by no means dominant) in the representations even if it is sometimes undermined: "I kept my own name when I got married because I am not a dog that has changed owners ... Some people think that it is because I work in the family business but I felt just as deeply about it before working here. I think I am just stroppy!” (1.3.96).

This shift might suggest that the increasing economic contribution of farm women to the survival of farm businesses is leading to the construction of alternative, even competing, versions of femininity in an agricultural context. However, far from a removal of emphasised femininity, articles continue to draw upon these constructions, but are replicating them in more subtle ways. For example, the celebration of business successes of farm women thinly disguises a commodification of women's reproductive roles within farm households, helping to legitimise their participation in these business activities. Furthermore, in both these and other types of article, women are more often than not described in relation to other household members, particularly as wives and mothers, rather than individuals in their own right (see also Walter and Wilson, 1996). Although there is a claim that Farmlife is for all the farming family and where, at first sight, articles may appear to have general appeal, there is an uneasy feeling that many articles are being selected on the basis of an anticipated indirect appeal to women structured according to pre-conceptions based on emphasised femininity. Examples include lead articles on wild flowers, rose growing, embroidery, varietal apple juice and animals (dogs and horses) which presumably have a female audience in mind. Seemingly new versions of femininity are constructed as a palimpsest under which emphasised femininity persists implicitly within these representations. In contrast, hegemonic masculinity remains explicit by continued reference to the agricultural business activities of men. The evidence suggests that this dualistic interpretation of gender identities has proved remarkably resilient over the 20 years examined and that profound restructuring within the agricultural industry has done little to challenge them. This is not to deny that farm women are now involved in a wider variety of activities and have taken greater charge of their lives than depicted in 1976. 
However, Farmlife does little to reflect these changes, so there appears to be a trend of divergence between representation and reality. It is increasingly presenting a misleading picture of farming femininities and so fails to challenge traditional, and well-established constructions of gender identities in UK agriculture. Importantly, the analysis reveals that this is often covert, finding parity with research conducted outside the UK. Further research is needed to uncover the reasons for this, but it can be suggested that an inherent conservatism within agricultural communities and an ideologically-loaded construction of farming as a particular type of rural activity play their part (McDowell and Massey, 1984; Morris and Evans, 1999). A possible consequence of this is that "if the farm magazine narrative stereotypes women's participation in commodity production or undervalues their contribution to farm household survival it strengthens the traditional domestic ideology that limits recognition of women's roles in farm and home" (Walter and Wilson, 1996, p.230-231).

It would be all too easy to condemn Farmlife on this count, yet some value to its existence can be demonstrated. Unlike the occasional representations of women in the main pages of the farming media, the women in Farmlife are described in detail, they are often the central focus and the articles are replete with their biographical details. In this sense, Farmlife has increasingly provided farm women with a space of representation that is largely theirs, albeit from within the constraints of preconceptions about family and femininity within the agricultural context. This stands in contrast to the 'farm success stories' reported in the American farming press (Walter and Wilson, 1996), and within the Australian agricultural press where "males populate the visual and rhetorical representations of agriculture almost exclusively"(Leipins, 1996, p.5). There is agreement with Walter and Wilson (1996) that the versions of femininity portrayed in Farmlife are not based upon commodity production roles, but caution needs to be exercised as this is not the purpose of Farmlife. With the 'household' focus of Farmlife, it might be unrealistic to expect considerable attention to be paid to farm women's roles in commodity production, unlike in Walter and Wilson's (1996) farmer success stories. Even so, it does not seem unreasonable to expect some explicit recognition, even celebration, of the crucial contribution to the reproduction of the farm business that farm women play in their domestic duties, a feature currently absent from Farmlife. This lies far from demanding that Farmlife become a more radical forum for the discussion of a much wider range of issues which are known to be impacting upon farm family life and of particular relevance to the various meanings of being a woman in this context. 
This analysis of Farmlife would appear to support Walter and Wilson's (1996) assertion that farm magazines represent a further instance of popular culture supporting poor role models through portrayal of traditional versions of femininity and masculinity. However, further research is needed to discover whether farm women recognise themselves in the representations that Farmlife promotes, and if so, ascertain the extent to which these portrayals are appealing and meaningful. Such investigation is particularly pertinent given the general dearth of research with consumers of these products (Jackson and Thrift, 1995). Leipins (1996) has provided some evidence on how media texts are actively resisted and the various campaign methods employed by farm women to have their views and contributions to agriculture more accurately represented by the media. The types of role models that are presented to the readers of Farmlife and the influence of these in 'social learning' about gender identities requires empirical research with farmers and their wives. Hence, the next stage of the research project is to interview readers and discover if the ideal role models of 'supporting a husband in a difficult occupation' or 'maintaining a wholesome family way of life' found by this analysis to be codified in Farmlife are having an impact in reality.

\section{References}

AGG, JENNY \& PHILLIPS, MARTIN (1998) Neglected gender dimensions of rural social restructuring, in: PAUL BOYLE \& KEITH HALFACREE (Eds) Migration Into Rural Areas: Theories and Issues, pp. 252-279 (Chichester, Wiley and Sons).

ALMAS, REIDAR \& HAUGEN, MARIT (1991) Norwegian gender roles in transition: the masculinisation hypothesis in the past and in the future. Journal of Rural Studies, 7 (12), pp. 79-83.

ALSTON, MARGARET (1995) Women and their work on Australian farms. Rural Sociology, 60 (3), pp. 521-532.

ARGENT, NEIL. (1999) Inside the black box: dimensions of gender, generation and scale in the Australian rural restructuring process. Journal of Rural Studies, 15 (1), pp. 1-15. 
BRANDTH, BERIT (1995) Rural masculinity in transition: gender images in tractor advertisements. Journal of Rural Studies, 11 (2), pp. 123-133.

BRANDTH, BERIT \& HAUGEN, MARIT (1997) Rural women, feminism and the politics of identity. Sociologia Ruralis, 37 (3), pp. 325-344.

BURGESS, JACKIE (1990) The production and consumption of environmental meanings in the mass media: a research agenda for the 1990s. Transactions of the Institute of British Geographers, 15 (2), pp. 139-161.

BURGESS, JACKIE (1993) Representing nature: conservation and the mass media, in: FRANK GOLDSMITH \& ANDREW WARREN (Eds) Conservation in Progress, pp. (John Wiley).

BURGESS, JACKIE \& GOLD, JOHN (Eds) (1985) Geography, the Media and Popular Culture (London, Croom Helm).

BUTLER, JUDITH (1990) Gender Trouble (London, Routledge).

CLOKE, PAUL (1997) Country backwater to virtual village? Rural studies and the 'cultural turn'. Journal of Rural Studies, 13, pp. 367-75.

CONNELL, ROBERT (1987) Gender and Power: Society, the Person and Sexual Politics (Cambridge, Cambridge University Press).

EVANS, NICK \& ILBERY, BRIAN (1992) Farm-based accommodation and the restructuring of agriculture: evidence from three English counties. Journal of Rural Studies, 8, pp. 85-96.

EVANS, NICK \& ILBERY, BRIAN (1996) Exploring the influence of farm-based pluriactivity on gender relations in capitalist agriculture. Sociologia Ruralis, 36 (1), pp. 74-92. 
FISH, ROBERT \& PHILLIPS, MARTIN (1997) Explorations in media country: political economic moments in British rural television drama. Paper presented at the third BritishFrench Rural Geography Symposium, Nantes, September 1997.

FISHER, CLARE (1997) 'I bought my first saw with my maternity benefit': craft production in west Wales and the home as the space of (re)production, in: PAUL CLOKE \& JO LITTLE (Eds) Contested Countryside Cultures: Otherness, Marginalisation and Rurality, pp. 232-251 (London, Routledge).

GASSON, RUTH (1980) Roles of farm women in England. Sociologia Ruralis, 20, pp. 165180.

GASSON, RUTH (1982) Farmers' wives - their contribution to the farm business. Journal of Agricultural Economics, 43, pp. 74-87.

GASSON, RUTH \& ERRINGTON, ANDREW (1993) The Farm Family Business (Wallingford, CAB International).

GIDARAKOU, ISABELLA (1999) Young women's attitudes towards agriculture and women's new roles in the Greek countryside: a first approach. Journal of Rural Studies, 15 (2), pp. 147-158.

HANEY, WAVA \& MILLER, LORNA (1991) U.S. farm women, politics and policy. Journal of Rural Studies, 7 (1/2), pp. 115-121.

HUGHES, ANNIE (1997) Rurality and 'cultures of womanhood': domestic identities and moral order in village life, in: PAUL CLOKE \& JO LITTLE (Eds) Contested Countryside Cultures: Otherness, Marginalisation and Rurality, pp. 123-137 (London, Routledge).

JACKSON, PETER \& THRIFT, NIGEL (1995) Geographies of consumption, in: D MILLER (Ed) Acknowledging Consumption: a Review of New Studies, pp. 204-237 (London, Routledge). 
JACKSON, PETER; BROOKS, KATE \& STEVENSON, NICK (1999) Making sense of men's lifestyle magazines. Environment and Planning D: Society and Space, 17, pp. 353-368.

KEATING, NORAH \& LITTLE, HEATHER (1994) Getting into it: farm roles and careers of New Zealand women. Rural Sociology, 59 (4), pp. 720-736.

LECKIE, GLORIA (1996) 'They never trusted me to drive': farm girls and the gender relations of agricultural information transfer. Gender, Place and Culture, 3 (3), pp. 309-325

LEIPINS, RUTH (1995) Women in Agriculture: advocates for a gendered sustainable agriculture. Australian Geographer, 26 (2), pp. 118-126.

LEIPINS, RUTH (1996) Reading agricultural power: media as sites and processes in the construction of meaning. New Zealand Geographer, 52 (2), pp. 3-10.

LEIPINS, RUTH (1998) 'Women of broad vision': nature and gender in the environmental activism of Australia's "Women in Agriculture' movement. Environment and Planning A, 30, pp. 1179-1196.

LITTLE, JO \& AUSTIN, PATRICIA (1996) Women and the rural idyll. Journal of Rural Studies, 12 (2), pp. 101-111.

LITTLE, JO (1997a) Constructions of rural women's voluntary work. Gender, Place and Culture, 4 (2), pp. 197-209.

LITTLE, JO (1997b) Employment marginality and women's self-identity, in: PAUL CLOKE \& JO LITTLE (Eds) Contested Countryside Cultures: Otherness, Marginalisation and Rurality, pp. 138-157 (London, Routledge).

LITTLE, JO (1999) Otherness, representation and the cultural construction of rurality. Progress in Human Geography, 23 (3), pp. 437-442. 
LOWE, PHILLIP \& MORRISON, DAVID (1984) Bad news or good news: environmental politics and the mass media. Sociological Review, pp. 75-90.

MACKENZIE, FIONA (1994) Is where I sit, where I stand? The Ontario Farm Women's Network, politics and difference. Journal of Rural Studies, 10 (2), pp. 101-115.

MARSDEN, TERRY, MUNTON, RICHARD, WHATMORE, SARAH, LITTLE, JO (1989)

Strategies for coping in capitalist agriculture: a British perspective. Geoforum, 20, pp. 1-14.

MARSDEN, TERRY, MURDOCH, JONATHON, LOWE, PHILIP, MUNTON, RICHARD \& FLYNN, ANDREW (1993) Constructing the Countryside (London, UCL Press).

MASSEY, DOREEN (1994) Space, Place and Gender. (Cambridge, Polity).

MASSEY, DOREEN (1996) Masculinity, dualisms and high technology, in: NANCY DUNCAN (Ed) Body Space: Destabilising Geographies of Gender and Sexuality, pp.109-126 (London: Routledge).

MCDOWELL, LINDA \& MASSEY, DOREEN (1984) A woman's place, in: DOREEN MASSEY \& JOHN ALLEN (Eds) Geography Matters, pp.128-147 (Cambridge: Cambridge University Press).

MCHENRY, HELEN (1996) Farming and environmental discourses: a study of the depiction of environmental issues in a German farming newspaper. Journal of Rural Studies, 12 (4), pp. 375-386.

MORRIS, CAROL \& EVANS, NICK (1999) Research on the geography of agricultural change: redundant or revitalised? Area, 31 (4), pp.349-358.

MURDOCH, JONATHAN \& MARSDEN, TERRY (1994) Reconstituting Rurality: Class, Community and Power in the Development Process (London, UCL Press). 
MURDOCH, JONATHAN \& PRATT, ANDY (1993) Rural studies, modernism, postmodernism and the 'post rural'. Journal of Rural Studies, 9 (4), pp. 411-27.

NEWBY, HOWARD (1979) Green and Pleasant Land? Social Change in Rural England (London, Hutchinson).

PARISI, PETER \& HOLCOMB, BRIAVEL (1994) Symbolising place: journalistic narratives of the city. Urban Geography, 15 (4), pp. 376-394.

PHILO, CHRIS (1993) Postmodern rural geography? A reply to Murdoch and Pratt. Journal of Rural Studies, 9 (4), pp. 429-436.

PHILLIPS, MARTIN (1998) The restructuring of social imaginations in rural geography. Journal of Rural Studies, 14, pp.121-153.

ROGERS, ANNE (1997) Personal communication from the (then) editor of Farmlife.

ROSE, GILLIAN (1993) Feminism and Geography: the Limits to Geographical Knowledge. (Cambridge, Polity).

SHAVER, FRANCES (1991) Women, work and the evolution of agriculture. Journal of Rural Studies, 7 (1/2), pp. 37-43.

SHORT, JOHN-RENNIE (1991) Imagined Country (London, Routledge).

SHORTALL, SALLY (1992) Power analysis and farm wives: an empirical study of the power relationships affecting women on Irish farms. Sociologia Ruralis, 32 (4), pp. 431-451.

TEATHER, ELIZABETH (1996) Farm women in Canada, New Zealand and Australia redefine their rurality. Journal of Rural Studies, 12 (1), pp. 1-14.

WALTER, GERRY \& WILSON, SUSANNE (1996) Silent partners: women in farm magazine success stories, 1934-1991. Rural Sociology, 61 (2), pp. 227-248. 
WHATMORE, SARAH (1991a) Farming Women: Gender Work and Family Enterprise (London, Macmillan).

WHATMORE, SARAH(1991b) Life cycle or patriarchy? Gender divisions in family farming. Journal of Rural Studies, 7 (12), pp. 71-76.

WHATMORE, SARAH, MARSDEN, TERRY \& LOWE, PHILLIP (Eds) (1994) Gender and Rurality, Critical Perspectives on Rural Change Series (London, David Fulton).

WOMEN AND GEOGRAPHY STUDY GROUP (1997) Feminist Geographies: Explorations in Diversity and Difference (Harlow: Longman).

YARWOOD, RICHARD \& EVANS, NICK (2000) Taking stock of farm animals and rurality, in: CHRIS PHILO (Ed) Animal Places, Beastly Spaces (London, Routledge). 
Figure 1. A typology of Farmlife articles

\begin{tabular}{|c|c|}
\hline Type of article & Description \\
\hline Operating a business & $\begin{array}{l}\text { Production of goods on a commercial scale. Examples include } \\
\text { commercial farming itself, value-added agricultural production } \\
\text { such as cheese-making, non-agricultural business activity such } \\
\text { as farm house accommodation. }\end{array}$ \\
\hline $\begin{array}{l}\text { Rural community } \\
\text { life }\end{array}$ & $\begin{array}{l}\text { The contribution of the individual reported to life in the } \\
\text { farming community and wider rural community. For example } \\
\text { farm shows, rural community life involving customs / folklore, } \\
\text { quality of rural life issues and fund-raising. }\end{array}$ \\
\hline The domestic sphere & $\begin{array}{l}\text { Focused on personal and household aspects of (farm) family } \\
\text { life, such as cookery competitions, love stories and } \\
\text { relationships with farm children. This implies an element of } \\
\text { constraint/obligation to distinguish it from a recreational } \\
\text { activity. }\end{array}$ \\
\hline $\begin{array}{l}\text { Recreational } \\
\text { pursuits }\end{array}$ & $\begin{array}{l}\text { Participation in a leisure activity such as a sport, usually } \\
\text { off-farm. Implies an ability to choose to undertake an activity } \\
\text { (to distinguish it from a domestic one). }\end{array}$ \\
\hline Craft activities & $\begin{array}{l}\text { Production of a (traditional) product on a small, non- } \\
\text { commercial scale typically on-farm, for ones own pleasure } \\
\text { such as rug-making or silversmithing. }\end{array}$ \\
\hline Politics & $\begin{array}{l}\text { Policy issues such as closure of rural railways, or participation } \\
\text { of the individual reported on in rural political life. }\end{array}$ \\
\hline Conservation & $\begin{array}{l}\text { Reporting examples of environmentally friendly farming. } \\
\text { Although an outcome of agricultural policy change in the } \\
1980 \text { s and } 90 \text { s, this category is distinguished from 'politics' } \\
\text { through its focus on the practical aspects of on-farm } \\
\text { environmental management. }\end{array}$ \\
\hline
\end{tabular}


Table I. Dominant theme in lead articles (\% no.) 1976 and 1996

Table II. Dominant theme in lead articles (\% no. ) where women are represented as central to the article 
Table I.

\begin{tabular}{|l|c|c|}
\hline \multirow{2}{*}{ Dominant theme in lead article } & \multicolumn{2}{|c|}{ \% no. of articles in each year } \\
\cline { 2 - 3 } & $\mathbf{1 9 7 6}$ & $\mathbf{1 9 9 6}$ \\
\hline Operating a business & 22 & 48 \\
\hline Rural community life & 20 & 16 \\
\hline The domestic sphere & 22 & 4 \\
\hline Recreational pursuits & 22 & 22 \\
\hline Craft activities & 10 & 4 \\
\hline Politics & 6 & 0 \\
\hline Conservation & 0 & 100 \\
\hline Total & 100 & 6 \\
\hline
\end{tabular}


Table II.

\begin{tabular}{|l|c|c|}
\hline \multirow{2}{*}{ Dominant theme in lead article } & \multicolumn{2}{|c|}{ \% no. of articles in each year } \\
\cline { 2 - 3 } & $\mathbf{1 9 7 6}$ & $\mathbf{1 9 9 6}$ \\
\hline Operating a business & 23 & 53 \\
\hline Rural community life & 8 & 16 \\
\hline The domestic sphere & 31 & 0 \\
\hline Recreational pursuits & 23 & 21 \\
\hline Craft activities & 15 & 0 \\
\hline Politics & 0 & 0 \\
\hline Conservation & 0 & 11 \\
\hline Total & 100 & 00 \\
\hline
\end{tabular}

